\title{
Cytokeratins 7 and 20 Immunoreactivity in Chromophobe Renal Cell Carcinomas and Renal Oncocytomas
}

Sang Ling Wu, M.D., Pulin Kothari, M.D., Thomas M. Wheeler, M.D., Tommy Reese, M.T.(ASCP), John H. Connelly, M.D.

Department of Pathology and Laboratory Medicine, University of Texas-Houston Medical School (SLW, JHC); Department of Pathology and Laboratory Medicine, Baylor College of Medicine (PK, TMW); Department of Pathology, St. Luke's Episcopal Hospital (TR, JHC); Houston, Texas

Chromophobe renal cell carcinomas and renal oncocytomas share morphologic similarities and may present a diagnostic challenge on routine hematoxylin-eosin staining. Currently recommended additional studies of Hale's colloidal iron staining and electron microscopy are often difficult to interpret and technically challenging and may not be readily available. Previous studies have reported conflicting results with regard to the cytokeratin 7 staining pattern in chromophobe renal cell carcinomas and renal oncocytomas. Cytokeratin 20 expression in chromophobe renal cell carcinomas has not previously been studied. Formalin-fixed paraffinembedded tissue of 11 chromophobe renal cell carcinomas and 21 renal oncocytomas were retrieved from the archived files (1984-2000) of four teaching hospitals. Of the 11 chromophobe renal cell carcinomas, eight stained positive $\mathbf{( 7 3 \% )}$ for cytokeratin 7 , one stained focally positive $(9 \%)$, and two cases (18\%) were completely negative. Cytokeratin 7 staining of the 21 oncocytomas revealed 4 positive (19\%), 7 focally positive (33\%), and 10 negative cases (48\%). Cytokeratin 20 was uniformly negative on all 11 cases of chromophobe renal cell carcinomas and all 21 cases of oncocytomas. Cytokeratin 7 does not appear to show the consistent immunoreactivity in chromophobe renal cell carcinomas and renal oncocytomas, as has been previously suggested. Cytokeratin 20 immunostaining in chromo-

Copyright (C) 2002 by The United States and Canadian Academy of Pathology, Inc.

VOL. 15, NO. 7, P. 712, 2002 Printed in the U.S.A.

Date of acceptance: March 22, 2002.

Presented in part as a poster at the 90th Annual Meeting of the United States and Canadian Academy of Pathology in Atlanta, GA on March 3-9, 2001.

Address reprint requests to: Sang Ling Wu, M.D., Department of Pathology and Laboratory Medicine, University of Texas-Houston Medical School, 6431 Fannin Street, Houston, TX 77030; e-mail: sang.ling.wu@ uth.tmc.edu; fax: 713-500-0730.

DOI: $10.1097 / 01 . M P .0000017566 .29755 .8 A$ phobe renal cell carcinomas and renal oncocytomas is uniformly negative. Despite the technical and interpretive challenges of Hale's colloidal iron, it is still the most useful stain in differentiating chromophobe renal cell carcinomas from renal oncocytomas.

KEY WORDS: Chromophobe renal cell carcinoma, Cytokeratin 7, Cytokeratin 20, Immunohistochemistry, Renal oncocytoma.

Mod Pathol 2002;15(7):712-717

Chromophobe renal cell carcinoma is a distinct subtype of renal cell carcinoma first described in humans by Thoenes in 1985 (1). Chromophobe renal cell carcinomas have characteristic morphologic features of broad trabeculae of polygonal cells with clear to granular cytoplasm, prominent cell borders, wrinkled nuclear membranes, and frequent multinucleation (2-4). Ultrastructural examination of chromophobe cells containing prominent intracytoplasmic microvesicles between 250 $400 \mathrm{~nm}$ in diameter represents the traditional gold standard for diagnosis (5). Chromophobe renal cell carcinomas, particularly the eosinophilic variants, may resemble renal oncocytomas on routine hematoxylin-eosin stains. Accurate distinction of chromophobe renal cell carcinomas from renal oncocytomas has significant prognostic implications because aggressive behavior of chromophobe renal cell carcinomas has been reported, whereas an overwhelming majority of oncocytomas are benign and do not metastasize (6-8).

In recent years, multiple studies have explored the potential utility of special staining techniques and immunohistochemistry in differentiating renal neoplasms with eosinophilic, or "granular," cytoplasm (9-18). Early enthusiasm for Hale's colloidal iron resulted from the strong and diffusely positive reticular staining pattern reported in chromophobe 
renal cell carcinomas. However, further elucidation of the Hale's colloidal iron stain reveals variable positivity and staining patterns in oncocytomas and other renal cell carcinomas. Therefore, proper interpretation of Hale's colloidal iron requires experience in recognizing different staining patterns rather than simply identifying positivity (14). Technical difficulties, variable staining, and poor correlation among different laboratories also complicate the overall utility of Hale's colloidal iron.

Subsequently, the possible role of immunohistochemistry in distinguishing chromophobe renal cell carcinomas from renal oncocytomas has been explored. In particular, cytokeratins (CKs) 7 and 20 have generated interest because of their wellrecognized utility in determining the site of origin of metastatic carcinomas of unknown primary origin (19-21). Published reports on the CK 7 immunostaining of chromophobe renal cell carcinomas have produced conflicting results. Leroy et al. (17) concluded that CK 7 may be useful in the differential diagnosis of chromophobe renal cell carcinomas and renal oncocytomas, whereas Taki et al. (16) reported that their cytokeratin profile (including CK 7) was inconsistent and therefore not useful in distinguishing the two entities. The CK 20 profile for chromophobe renal cell carcinomas has not previously been studied. A recent brief report on CK 20 staining in oncocytomas demonstrated $80 \%$ positivity with variable patterns and distribütions (18).

\section{MATERIAL AND METHODS}

Formalin-fixed paraffin-embedded tissue of 11 chromophobe renal cell carcinomas and 21 renal oncocytomas were retrieved from the archived files of the following four teaching hospitals in Houston, Texas: Memorial Hermann Hospital (1984-2000), St. Luke's Episcopal Hospital (1993-2000), Methodist Hospital (1997-2000), and Lyndon B. Johnson General Hospital (1999-2000).

Consecutive paraffin sections were cut at $4 \mu \mathrm{m}$ and placed on poly-L-lysine slides. The sections were sequentially treated with a primary monoclonal antiserum, mouse biotinylated antibody, labeling reagent (avidin-biotin complex), and a chromogenic substrate system (3,3' diaminobenzidine). All 32 cases were stained with CK 7 (DAKO Corporation, clone 12/30, 1:100 dilution), CK 20 (DAKO, clone 20.8, 1:100 dilution), and Hale's colloidal iron with slight modifications (sections were treated with $12 \%$ acetic acid before adding the colloidal iron solution; 14). Appropriate positive and negative controls were performed. Two of the authors (SLW and JHC) reviewed all slides. The percentage of reactive neoplastic cells was quantified as $0 \%$ (negative), $<5 \%$ (focally positive), or $>5 \%$ (posi- tive), consistent with the values established by previous immunohistochemical studies (19-21).

Electron microscopy was performed in 10 cases (five chromophobe renal cell carcinomas and five renal oncocytomas) to establish a diagnostic gold standard in selected cases. Specimens were deparaffinized with xylene and fixed with $3 \%$ glutaraldehyde. Thin sections were taken and stained with uranyl acetate and lead nitrate, and subsequent photographs were taken on the JEOL 1200EX electron microscope.

\section{RESULTS}

Of the 11 chromophobe renal cell carcinomas, 8 stained positive (73\%) for CK 7 (Fig. 1), 1 stained focally positive (9\%), and 2 cases (18\%) were completely negative (Fig. 2). CK 7 staining of the 21 renal oncocytomas revealed 4 positive (19\%; Fig. 3 ), 7 focally positive (33\%; Fig. 4), and 10 negative (48\%) cases. In chromophobe renal cell carcinomas, positivity was diffuse throughout the cytoplasm of the tumor cells with accentuated cell membrane intensity. CK 7 positivity in renal oncocytomas exhibits similar cytoplasmic intensity without peripheral accentuation. The prominent cytoplasmic CK 7 staining of the normal glomerular and tubular structures served as appropriate internal controls.

CK 20 was uniformly negative on all 11 cases of chromophobe renal cell carcinomas (Fig. 5) and all 21 cases of renal oncocytomas (Fig. 6). All glomeruli and tubules of the adjacent uninvolved kidney also stained negative for CK 20.

Hale's colloidal iron showed cytoplasmic positivity in 10 of 11 chromophobe renal cell carcinomas $(91 \%)$ and exhibited the diffuse, meshwork-like reticular pattern described by Tickoo et al. (15). The remaining case was completely negative (Table 1 ). Fourteen of the 21 renal oncocytomas stained positive or focally positive for Hale's colloidal iron (67\%). The staining pattern in renal oncocytomas consisted of fine, dustlike granules in the cytoplasm or concentrated cytoplasmic staining in the luminal aspect of the tumor cells, as previously described. The remaining seven oncocytomas were negative for Hale's colloidal iron (Table 2).

Ultrastructural studies were performed on 10 random cases, including the two cases of CK 7-negative chromophobe renal cell carcinomas and the four cases of CK 7-positive renal oncocytomas. All five cases of chromophobe renal cell carcinomas revealed distinct foci of characteristic cytoplasmic microvesicles varying between 250-400 nm with occasional inner vesicles. The five cases of renal oncocytomas revealed abundant mitochondria with lamellar cristae. 


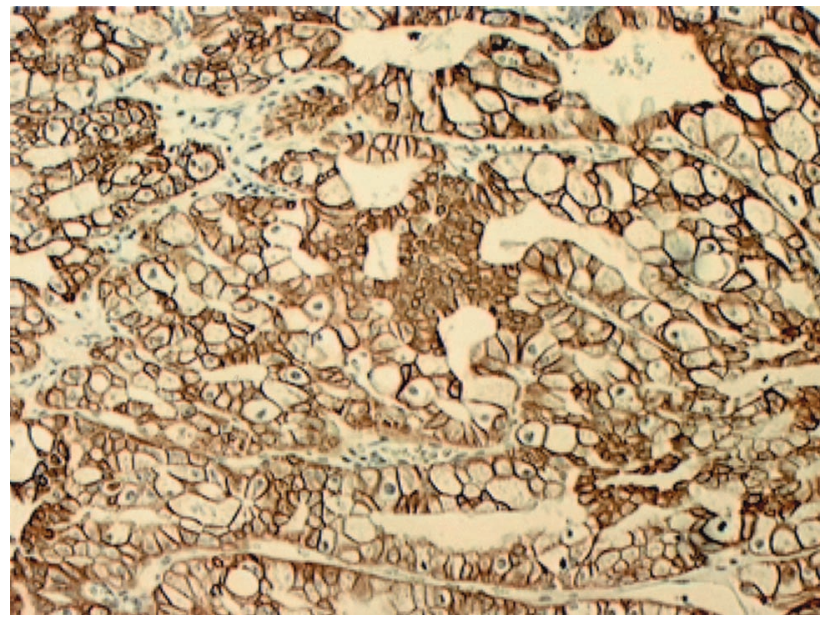

FIGURE 1. Chromophobe renal cell carcinoma (Case 9) exhibits diffuse cytokeratin 7 (CK 7) positivity with accentuated cell membrane intensity (CK 7, clone 12/30, 100×).

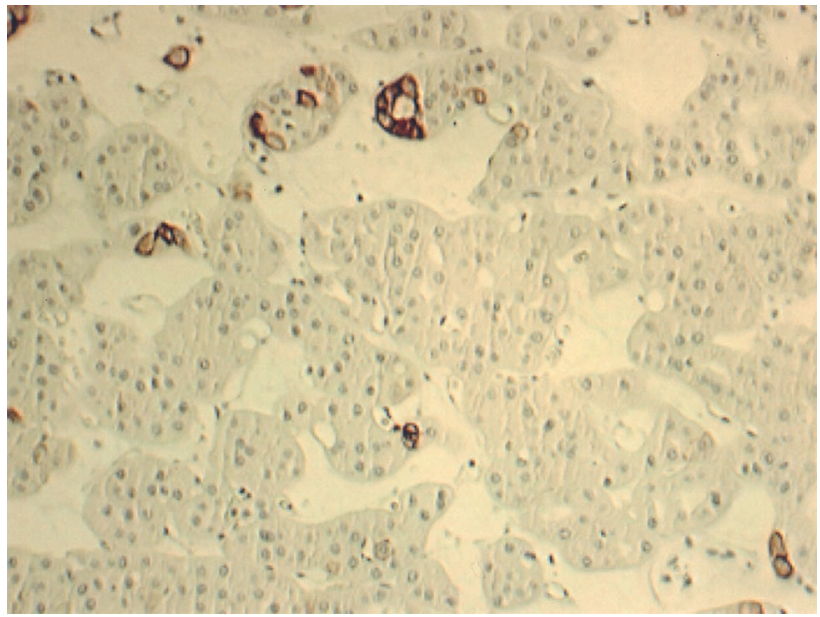

FIGURE 4. Renal oncocytoma (Case 19) exhibits focal positivity for cytokeratin 7 (CK 7 , clone $12 / 30,100 \times$ ).

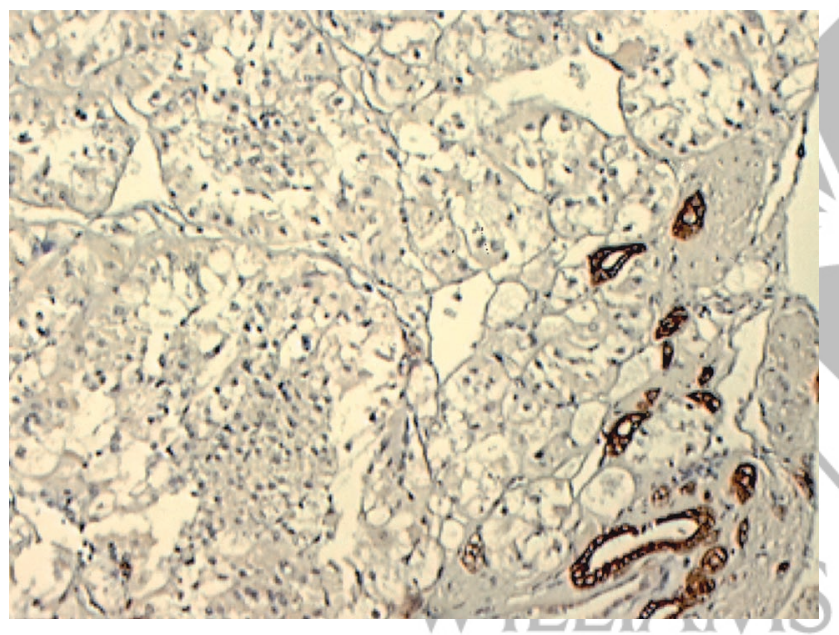

FIGURE 2. Chromophobe renal cell carcinoma (Case 1) is completely negative for cytokeratin 7 , with normal tubular epithelium as internal positive control (CK 7, clone 12/30, 100×).

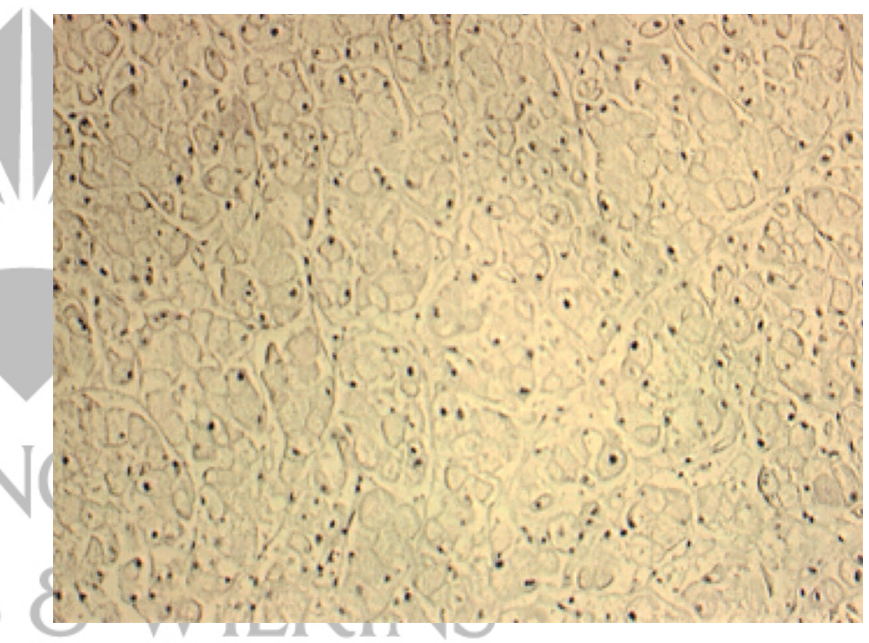

FIGURE 5. Chromophobe renal cell carcinoma (Case 5) is completely negative for cytokeratin 20 (CK 20, clone 20.8, 100×).

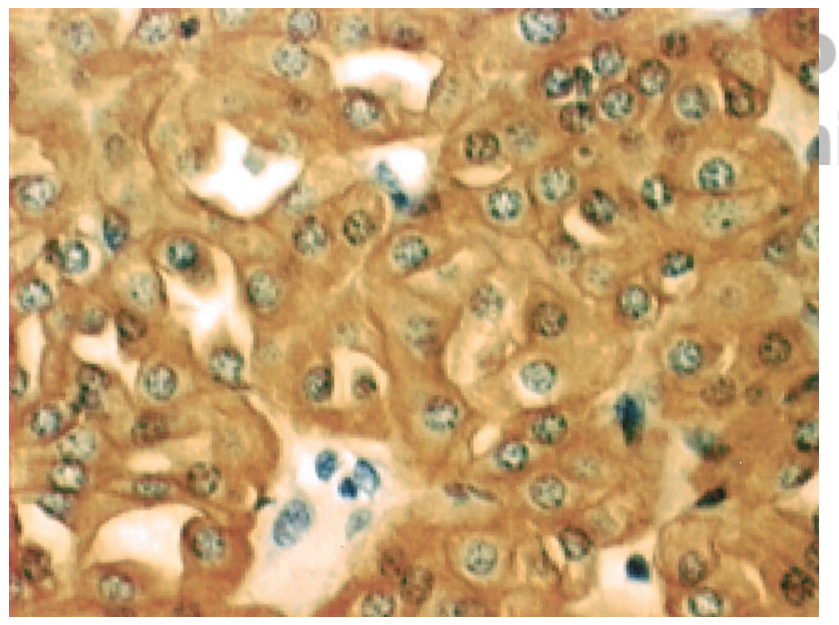

FIGURE 3. Renal oncocytoma (Case 5) shows strong cytoplasmic, granular positivity for cytokeratin 7 (CK 7, clone 12/30, 200×).

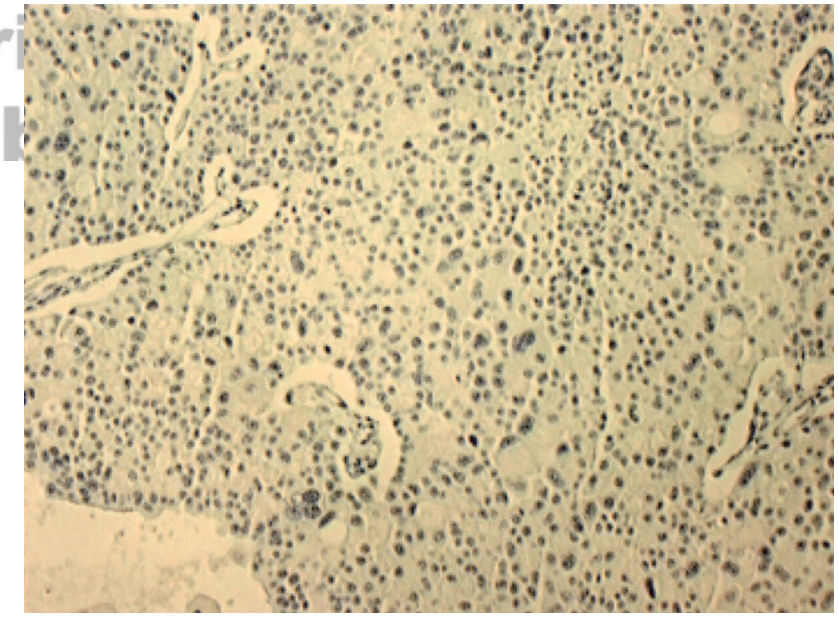

FIGURE 6. Renal oncocytoma is completely negative for cytokeratin 20 (CK 20, clone 20.8, 100×). 


\begin{tabular}{|c|c|c|c|c|c|}
\hline Case & Age (y)/Sex & $\begin{array}{c}\text { Tumor Size }(\mathrm{cm}), \\
\text { Laterality }\end{array}$ & CK-7 & CK-20 & Hale's Colloidal Iron \\
\hline 1 & $65 / \mathrm{F}$ & $2.3, \mathrm{R}$ & - & - & + , reticular \\
\hline 2 & $39 / \mathrm{F}$ & $9.3, \mathrm{R}$ & + & - & + , reticular \\
\hline 3 & $53 / \mathrm{F}$ & 8.7, L & + & - & + , reticular \\
\hline 4 & $36 / \mathrm{M}$ & $5.2, \mathrm{R}$ & + & - & - \\
\hline 5 & $62 / \mathrm{F}$ & 13.0, R & + & - & + , reticular \\
\hline 6 & $81 / \mathrm{F}$ & $16.0, \mathrm{R}$ & - & - & + , reticular \\
\hline 7 & $60 / \mathrm{M}$ & 3.0, L & Focal + & - & + , reticular \\
\hline 8 & $26 / \mathrm{F}$ & $12.0, \mathrm{~L}$ & + & - & + , reticular \\
\hline 9 & $33 / \mathrm{F}$ & $4.7, \mathrm{R}$ & + & - & + , reticular \\
\hline 10 & $73 / \mathrm{F}$ & $3.8, \mathrm{~L}$ & + & - & + , reticular \\
\hline 11 & $48 / \mathrm{F}$ & $1.5, \mathrm{~L}$ & + & - & + , reticular \\
\hline
\end{tabular}

CK, cytokeratin; F, female; M, male; R, right; L, left; +, positive; -, negative.

TABLE 2. Renal Oncocytomas

\begin{tabular}{|c|c|c|c|c|c|}
\hline Case & Age (y)/Sex & $\begin{array}{c}\text { Tumor Size }(\mathrm{cm}), \\
\text { Laterality }\end{array}$ & CK-7 & CK-20 & Hale's Colloidal Iron \\
\hline 1 & $64 / \mathrm{M}$ & 3.5, L & + & - & + , luminal \\
\hline 2 & $62 / \mathrm{M}$ & $4.0, \mathrm{~L}$ & Focal + & - & Focal + , dustlike \\
\hline 3 & $67 / \mathrm{M}$ & $9.5, \mathrm{R}$ & - & - & Focal + , dustlike \\
\hline 4 & $57 / \mathrm{M}$ & $5.3, \mathrm{R}$ & - & - & - \\
\hline 5 & $39 / \mathrm{F}$ & 3.7, L & + & - & + , luminal \\
\hline 6 & $45 / \mathrm{M}$ & $1.6, \mathrm{R}$ & + & - & Focal + , dustlike \\
\hline 7 & $71 / \mathrm{M}$ & $4.5, \mathrm{~L}$ & & - & + , dustlike \\
\hline 8 & $70 / \mathrm{M}$ & $2.9, \mathrm{~L}$ & - & - & - \\
\hline 9 & $58 / \mathrm{M}$ & $5.0, \mathrm{R}$ & Focal + & - & + , dustlike \\
\hline 10 & $72 / \mathrm{M}$ & $11.5, \mathrm{R}$ & - & - & - \\
\hline 11 & $90 / \mathrm{M}$ & $2.1, \mathrm{R}$ & Focal + & - & + , luminal \\
\hline 12 & $72 / \mathrm{M}$ & $8.0, \mathrm{R}$ & Focal + & - & Focal + , dustlike \\
\hline 13 & $52 / \mathrm{M}$ & 7.6, R & + & - & - \\
\hline 14 & $83 / \mathrm{F}$ & 8.5, R & - & - & Focal + , dustlike \\
\hline 15 & $65 / \mathrm{M}$ & $1.7, \mathrm{R}$ & - & - & - \\
\hline 16 & $61 / \mathrm{M}$ & $1.7, \mathrm{R}$ & - & - & - \\
\hline 17 & $84 / \mathrm{M}$ & $2.5, \mathrm{R}$ & & - & + , dustlike \\
\hline 18 & $79 / \mathrm{M}$ & $3.2, \mathrm{~L}$ & Focal & - & - \\
\hline 19 & $56 / \mathrm{M}$ & $4.2, \mathrm{R}$ & Focal + & - & + , dustlike \\
\hline 20 & $80 / \mathrm{M}$ & $0.9, \mathrm{~L}$ & & & + , dustlike \\
\hline 21 & $69 / \mathrm{M}$ & & & & Focal + , dustlike \\
\hline
\end{tabular}

CK, cytokeratin; F, female; M, male; R, right; L, left; +, positive; - , negative.

\section{DISCUSSION}

Cytokeratins are a class of intermediate filaments (7 to $11 \mathrm{~nm}$ ) which form the major structural proteins in eukaryotic cells. Polyclonal and monoclonal antibodies to cytokeratins are widely used in the differential diagnosis of numerous carcinomas of epithelial origin. Recent literature has characterized the diverse and unique expression of CKs 7 and 20 in epithelial neoplasms from various organ systems (19-23). The correlation of CK 7 and CK 20 expression is particularly helpful in distinguishing primary breast, lung, and ovarian carcinomas (CK 7 positive, CK 20 negative) from primary colon and Merkel cell carcinomas (CK 7 negative, CK 20 positive). Pancreatic carcinomas and cholangiocarcinomas may coexpress CKs 7 and 20, whereas adrenal cortical carcinomas, prostatic carcinomas, and thymomas generally do not express either CK 7 or CK 20.

CK 7 has been reported to be generally negative in conventional renal cell carcinomas with positiv- ity ranging from $4.8 \%$ to $10.5 \%$ (16). CK 7 immunoreactivity in papillary renal cell carcinomas is positive in low-grade tumors but is generally negative in tumors with high-grade nuclei (24). In chromophobe renal cell carcinomas, however, two previous studies have reported disparate results $(16,17)$. Taki et al. (16) reported that $43 \%$ of chromophobe renal cell carcinomas (9/21 cases) were positive for CK 7 , whereas Leroy et al. (17) reported $100 \%$ positivity (6/6 cases). Both studies reported a characteristic cytoplasmic staining for CK 7 with frequent peripheral accentuation. The two studies also reported conflicting results for CK 7 expression in renal oncocytomas; Taki et al. (16) reported focal CK 7 positivity in all three cases of oncocytomas, whereas Leroy et al. (17) reported focal positivity in only $3 / 11$ cases. Leroy et al. (17) proceeded to conclude that immunohistochemical staining for CK 7 might be useful in the differential diagnosis of chromophobe renal cell carcinomas and renal oncocytomas. In our study, however, we are unable to arrive 
at the same conclusion because of the following observations: (1) two cases of chromophobe renal cell carcinomas in our study are completely negative for CK 7; (2) 4 of 21 renal oncocytomas are positive for $\mathrm{CK} 7$, with seven additional cases exhibiting focal positivity; and (3) electron microscopy confirms the diagnosis in the two cases of CK 7-negative chromophobe renal cell carcinomas and the four cases of CK 7-positive oncocytomas. A comparison of the materials and methods of each study reveals relative consistency; both aforementioned studies and our study used the CK 7 antibody (clone OV-TL12/30) manufactured by DAKO Corporation. Possible factors contributing to the variability of CK 7 staining reported in chromophobe renal cell carcinomas and renal oncocytomas include the relative small number of total cases, interobserver variability in interpreting positivity, inadequate sampling, and inaccurate initial diagnosis. A recent study using comparative genomic hybridization also suggested that chromophobe renal cell carcinomas and renal oncocytomas represent a morphologic and genetic continuum with a subset of cases having overlapping phenotypic features, which may also contribute to variable immunohistochemical expression (25). Furthermore, it is important to recognize inherent limitations of immunohistochemical studies on paraffin-embedded chromophobe renal cell carcinoma tissue caused by the partial destruction of microvesicles by dehydrating solvents (26).

CK 20 expression in renal neoplasms has generated limited initial interest. Early studies have indicated that CK 20 immunoreactivity in renal cell carcinomas is almost always negative (19-21). All of these studies involved conventional renal cell carcinomas, and CK 20 immunoreactivity in chromophobe renal cell carcinomas has not previously been described. We report 0 of 11 cases of chromophobe renal cell carcinomas staining positive for CK 20.

Interestingly, a recent brief report demonstrated $80 \%$ (12/15 cases) CK 20 positivity in renal oncocytomas (18). Their results appear contradictory to our findings of $0 \%(0 / 21$ cases) CK 20 positivity in renal oncocytomas. Subtle differences in the manufacturers' antibodies used in the two studies (clone K5 20.8, Ventana versus clone 20.8, DAKO), variable selection criteria, and a variable threshold for interpreting immunoreactivity may contribute to the apparent discrepancy. Another possible explanation of the dotlike CK 20 reactivity observed by Stoprya et al. (18) may involve anomalous antigen expression. This pattern of aberrant expression is observed with desmin in nonmyogenic tumors and may be observed in other antibodies. Nevertheless, results from our study suggest that CK 20 is not diagnostically helpful in distin- guishing chromophobe renal cell carcinomas from renal oncocytomas.

The diagnostic utility of either CK 7 or 20 in differentiating chromophobe renal cell carcinomas from renal oncocytomas remains somewhat controversial at this point in time. Further standardized studies with more cases are necessary to conclusively establish and confirm the CK 7-CK 20 profile of chromophobe renal cell carcinomas and renal oncocytomas.

Hale's colloidal iron positivity is recognized as a distinct feature of chromophobe renal cell carcinomas. Tickoo et al. (14) performed a comprehensive study on colloidal iron staining in renal epithelial neoplasms with emphasis on technique and staining pattern. They reported difficulty in distinguishing positivity in the traditional Hale's colloidal iron stain and recommended a slightly modified Hale's colloidal iron-staining technique (also known as modified Mowry's). We observed a similar pattern of staining with the modified Hale's colloidal iron as those described by Tickoo et al. (14). Intense cytoplasmic positivity in a diffuse meshwork-like pattern was observed in 10/11 cases of chromophobe renal cell carcinomas. Periluminal and cytoplasmic positivity in a dustlike, granular pattern was observed in 14 of 21 cases of renal oncocytomas. Despite possible slight improvements in the sharpness of the reticular staining with this modified Hale's technique, the overall technical challenges remain. Examples of such challenges include maintaining an optimal $\mathrm{pH}$ of $<1.9$ and requiring daily preparations of the stock colloidal iron solution to ensure freshness (14). With optimal staining and a clear understanding of characteristic staining patterns, Hale's colloidal iron may still be useful in distinguishing chromophobe renal cell carcinomas from renal oncocytomas.

A single discriminatory stain to confidently distinguish all chromophobe renal cell carcinomas from renal oncocytomas has not yet been identified. In light of recent evidence of their overlapping continuum of morphologic, histochemical, and genetic features, discovering a $100 \%$ discriminatory stain may be unrealistic.

\section{CONCLUSION}

CK 7 does not appear to show the consistent immunoreactivity in chromophobe renal cell carcinomas and renal oncocytomas as has been previously suggested. CK 20 immunostaining in chromophobe renal cell carcinomas and renal oncocytomas was uniformly negative in our study. Despite the technical and interpretive challenges of Hale's colloidal iron, it is more useful than CK 7 in differentiating chromophobe renal cell carcinomas from renal oncocytomas. 


\section{REFERENCES}

1. Thoenes W, Störkel S, Rumpelt H. Human chromophobe cell renal carcinoma. Virchows Arch B (Cell Pathol) 1985;48:207.

2. Akhtar M, Kardar H, Linjawi T, et al. Chromophobe cell carcinoma of the kidney: a clinicopathologic study of 21 cases. Am J Surg Pathol 1995;19:1245-56.

3. Crotty TB, Farrow GM, Lieber MM. Chromophobe renal cell carcinoma: clinicopathologic features of 50 cases. J Urol 1995;154:964-7.

4. Tickoo SK, Amin MB. Discriminant analysis of nuclear features of chromophobe renal cell carcinoma and oncocytoma. Potential utility in their differential diagnosis. Am J Clin Pathol 1998;110:782-7.

5. Tickoo SK, Lee MW, Eble JN, Amin M, Christopherson T, et al. Ultrastructural observations on mitochondria and microvesicles in renal oncocytoma, chromophobe renal cell carcinoma, and eosinophilic variant of conventional (clear cell) renal cell carcinoma. Am J Surg Pathol 2000;24:1247-56.

6. Renshaw AA, Henske EP, Loughlin KR, et al. Aggressive variants of chromophobe renal cell carcinoma. Cancer 1996;78: 1756-61.

7. Perez-Ordonez B, Hamed G, Campbell S, et al. Renal oncocytoma: a clinicopathologic study of 70 cases. Am J Surg Pathol 1997;21:871-83.

8. Amin MB, Crotty TB, Tickoo SK, Farrow GM. Renal oncocytoma: a reappraisal of morphologic features with clinicopathologic findings in 80 cases. Am J Surg Pathol 1997;21:111 .

9. Beham A, Ratschek M, Zatloukal K, Schmid C, Denk H. Distribution of cytokeratins, vimentin, and desmoplakins in normal renal tissue, renal cell carcinomas and oncocytoma as revealed by immunofluorescence microscopy. Virchows Arch A Pathol Anat 1992;421:209-15.

10. Murphy WM, Beckwith JB, Farrow GM. Tumors of the kidney, bladder, and related urinary structures. In. Rosai J, editor. Atlas of tumor pathology. 3rd series. Fascicle 11. Washington, DC: Armed Forces Institute of Pathology; 1994. p. 1-192.

11. Bonsib SM. Renal chromophobe carcinoma: the relationship between cytoplasmic vesicles and colloidal iron stain. J Urol Pathol 1996;4:9-14.

12. Cochand-Priollet B, Molinié V, Bougaran J, Bouvier R, Dauge-Geffroy MC, et al. Renal chomophobe cell carcinoma and oncocytoma. A comparative morphologic, histochemical, and immunohistochemical study of 124 cases. Arch Pathol Lab Med 1997;121:1081-6.
13. Tickoo SK, Amin MB, Linden MD, et al. Antimitochondrial antibody (113-1) in the differential diagnosis of granular renal cell tumors. Am J Surg Pathol 1997;21:922-30.

14. Tickoo SK, Amin MB, Zarbo RJ. Colloidal iron staining in renal epithelial neoplasms, including chromophobe renal cell carcinoma. Am J Surg Pathol 1998;22:419-24.

15. Skinnider BJ, Jones EC. Renal oncocytoma and chromophobe renal cell carcinoma. A comparison of colloidal iron staining and electron microscopy. Am J Clin Pathol 1999;111: 796-803.

16. Taki A, Nakatani Y, Misugi K, Yao M, Nagashimi Y. Chromophobe renal cell carcinoma: an immunohistochemical study of 21 Japanese cases. Mod Pathol 1999;12:310-7.

17. Leroy X, Moukassa D, Copin M-C, Saint F, Mazeman E, Gosselin B. Utility of cytokeratin 7 for distinguishing chromophobe renal cell carcinoma from renal oncocytoma. Eur Urol 2000;37:484-7.

18. Stoprya GA, Warhol MJ, Multhaupt HA. Cytokeratin 20 immunoreactivity in renal oncocytomas. J Histochem Cytochem 2001;49:919-20.

19. Wang NP, Zee S, Zarbo RJ, et al. Coordinate expression of cytokeratins 7 and 20 defines unique subsets of carcinomas. Appl Immunohistochem 1995;3:99-107.

20. Moll R. Cytokeratins as markers of differentiation in the diagnosis of epithelial tumors. Subcell Biochem 1998;31: 205-61.

21. Chu PG, Wu E, Weiss LM. Cytokeratin 7 and cytokeratin 20 expression in epithelial neoplasms: a survey of 435 cases. Mod Pathol 2000;13:962-72.

22. Chan JKC, Wenig BM, Tsang WYW, et al. Cytokeratin 20 immunoreactivity distinguishes Merkel cell (primary cutaneous neuroendocrine) carcinomas and salivary gland small cell carcinomas from small cell carcinomas of various sites. Am J Surg Pathol 1997;21:226-34.

23. Wauters CC, Smedts F, Gerrits LG, et al. Keratin 7 and 20 as diagnostic markers of carcinomas metastatic to the ovary. Hum Pathol 1995;26:852-5.

24. Delahunt B, Eble JN. Papillary renal cell carcinoma: a clinicopathologic and immunohistochemical study of 105 tumors. Mod Pathol 1997;10:537-44.

25. Weirich G, Junker K, Salles PGO, et al. Comparative genomic hybridization analysis of renal oncocytomas (RO), chromophobe renal cell carcinomas (CHRCC) and tumors with hybrid histology-hybrid oncocytic tumors (HOT) [abstract]. Mod Pathol 2002;15:186A.

26. Bonsib SM, Bray C, Timmerman TG. Renal chromophobe cell carcinoma: limitations of paraffin-embedded tissue. Ultrastruct Pathol 1993;17:529-36. 